\title{
EXPERIMENTAL MEASUREMENT AT THE SEISMIC STATION OSTRAVA-KRÁSNÉ POLE (OKC): PRELIMINARY RESULTS AND REMARKS ON SITE EFFECT AT THE STUDIED LOCALITY
}

\author{
Markéta LEDNICKÁ * and Jana RUŠAJOVÁ \\ Department of Geomechanics and Mining Research, Institute of Geonics, Academy of Sciences of the Czech Republic, Studentská street 1768, \\ CZ-70800, Ostrava-Poruba, Czech Republic \\ *Corresponding author's e-mail: lednicka@ugn.cas.cz
}

\begin{tabular}{l} 
ARTICLE INFO \\
\hline Article history: \\
Received 8 July 2015 \\
Accepted 11 November 2015 \\
Available online 17 November 2015 \\
\hline
\end{tabular}

\section{Keywords:}

Seismic station $\mathrm{OKC}$

Spectral ratio

Site effect

FFT

\begin{abstract}
This paper presents some preliminary results and remarks on site effect at the locality of the seismic station Ostrava-Krásné Pole (OKC) which is part of the Czech regional seismological network. Short-term seismological measurements were realized simultaneously at two sites with different geological conditions using two identical seismic apparatuses GAIA Vistec and seismometers Lennartz LE3D/5s within the frequency range of 0.2 - $50 \mathrm{~Hz}$. Station "ST1" located in an experimental gallery represents a rock site formed by Carboniferous layers, while station "ST2" situated in a seismic cellar represents soil site with Quaternary sediments whose thickness amounts to roughly $16.5 \mathrm{~m}$. Seismic events and ambient noise recorded at stations ST1 and ST2 are analysed by three different spectral ratio methods - SSR, HVSR and HVNR and determined frequencies and amplifications are then compared. Analysed data set includes mainly mining induced seismic events from the Czech Republic (Ostrava-Karviná Coalfield) and mining induced seismic events from the Poland (Upper Silesian Coal Basin and Lubin).
\end{abstract}

\section{INTRODUCTION}

It is generally known that the characteristics of soil layers influence the increasing of seismic effect on the surface, so-called "site effect". The main reason is the effect of impedance contrast of surface soil layers to the underlined bedrock (e.g. Pitilakis, 2004). Impedance contrast between soil and bedrock layer causes that the seismic energy, propagating through the soil layer downwards to the bedrock, is reflected back to the soil layer. Due to this effect, the soil layer behaves as a resonator for certain frequency and it leads to the amplification of ground motion in this layer. The resonant frequency of soil layer depends mainly on the shear-wave velocity and thickness of this layer.

Evaluation of site effect is widely used for seismic engineering studies, microzonation studies and seismic hazard assessment (e.g. Ansal (ed.), 2004; Bard (ed.), 2008; Ansal et al., 2010; Panzera et al., 2013). To determine resonant frequency and amplification of ground motion in soil layers, spectral ratio methods are often used. Standard Spectral Ratio method (SSR) and Horizontal to Vertical Spectral Ratio method (HVSR) use records of seismic events, while the Horizontal to Vertical Noise Ratio method (HVNR) uses the records of ambient noise (Borcherdt, 1970; Lermo and Chávez-García, 1993; Nakamura, 1989). The SSR method is based on computing the Fourier spectral ratio of wave patterns simultaneously recorded by the horizontal components of two seismic stations, one of which is located on the bedrock and one is located on the soil site. The main difficulty associated with this technique is the necessity of existing reference site which means the outcrop of bedrock. Moreover, the correct use of the SSR technique requires the distance between the test and reference site to be significantly smaller than the epicentral distance of the recorded seismic event and the bedrock site should be free of any kind of site effect. The HVSR and HVNR techniques do not need a reference station and they are based on the computation of the horizontal-to-vertical spectral ratio of the components of motion recorded at only one seismic station. This technique is founded on the assumption that the vertical component of motion is not affected by local geological conditions.

The seismic station Ostrava-Krásné Pole (OKC) presents part of the Czech Regional Seismological Network and it is operated jointly by the VŠB Technical University of Ostrava, the Institute of Geonics Acad. Sci. Ostrava and the Geophysical Institute Acad. Sci. Prague (Holub et al., 2009). Since 1994 the readings of the station are being included in Bulletins of Czech seismological stations compiled by the Geophysical Institute Acad. Sci. Prague (www.czechgeo.cz). This station with continuous record is equipped with two types of sensors (three short period seismometers SM-3 and three-component broadband seismometer Guralp CMG-3ESP with T = $30 \mathrm{~s})$. These seismometers are installed in an 
experimental gallery on the bedrock outcrop at the depth approximately $10 \mathrm{~m}$ below the surface. Data acquisition system Quanterra Q330 S is situated at the Johann Palisa Astronomical Observatory in Ostrava at a distance approximately $430 \mathrm{~m}$ far from the experimental gallery. At the astronomical observatory, a seismic cellar is also located, which is underlined by the Quaternary sediments whose thickness amounts to roughly $16.5 \mathrm{~m}$.

In study by Holub et al. (2007) the significant amplification of seismic noise ground amplitudes was documented at the site of seismic cellar. Authors have analysed ambient noise vibrations mainly in time and amplitude domain to see differences in vibration amplitudes measured in the seismic cellar and experimental gallery, both during the night and the daytime. But no resonant frequency and amplification caused by the sedimentary layers at the place of seismic cellar was determined. Actual study is focused mainly on the frequency analysis of recorded seismic events and ambient noise to determine resonant frequency and amplification of the discussed soil site. At both places, i.e. at the seismic cellar and at the experimental gallery, short-term seismological measurement was realized at the beginning of the year 2015. This measurement has enabled simultaneous recording of seismic events in different geological conditions and the gathered data were analysed using different spectral ratio methods in frequency domain to determine site effect at the place of the seismic cellar. During the measurement in 2015 mostly records of mining induced seismic events form the Ostrava-Karviná Coalfield and from Poland were evaluated, as well as quarry blasts from nearby quarries.

\section{LOCALITY}

A sketch of distribution of temporary seismic stations ST1 and ST2 during the experimental measurement is presented in Figure 1. The studied

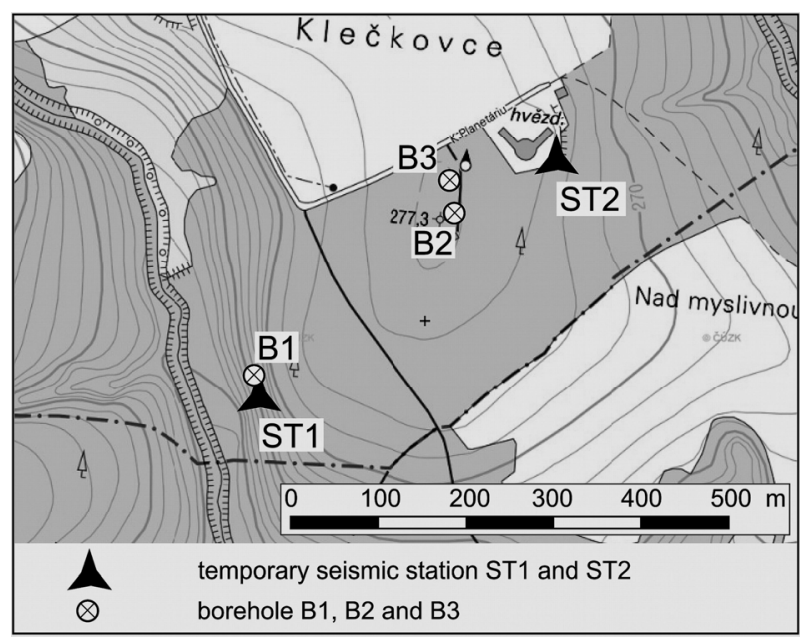

Fig. 1 Localization of temporary seismic stations ST1 and ST2 and the studied boreholes. area is located in the western part of Ostrava city, in the Ostrava-Krásné Pole quarter. Selected boreholes are also displayed in Figure 1 to provide information about the thickness of sedimentary layers at the studied locality. Station ST1 was located in the experimental gallery at the level of approximately $\mathrm{h}=+250 \mathrm{~m}$ in the depth of $10 \mathrm{~m}$ below the surface (Fig. 2). According to borehole B1, which is located near the station, there is a layer of weathered slates of the Carboniferous age at the depth of $10 \mathrm{~m}$ below the surface (Table 1). The existence of weathered rock layers may also result in the site effect (Steidl et al., 1996), so it will be necessary to investigate this possible effect during the analysis of the measured data, e.g. through an evaluation of seismic noise measured at this place using HVNR method. Seismic station ST2 was located on the seismic pillar of the seismic cellar at the level of approximately $\mathrm{h}=$ $+272 \mathrm{~m}$ (Fig. 3). According the geological documentation (internal report of the VŠB - Technical University of Ostrava, 1981) there are Quaternary sediments consisting of loams, sands and gravel in the thickness $16.5 \mathrm{~m}$ above the Carboniferous layers consisting of siltstone and claystone. At the profile between seismic stations ST1 and ST2, there are another two boreholes that document the decreasing thickness of Quaternary sediments towards station ST1.

The distance between seismic stations ST1 and ST2 was $450 \mathrm{~m}$ and the epicentral distances of recorded events were in the range from 18 to $230 \mathrm{~km}$. It means that the distance between the bedrock site and soil site is significantly smaller than the epicentral distances of recorded seismic events, so that it is possible to use the SSR method for data elaboration.

\section{EXPERIMENTAL MEASUREMENT}

The experimental short-time seismic measurement was performed simultaneously at stations ST1 and ST2 at the beginning of the year 2015. Duration of this measurement was almost three months. Seismic recorders GAIA Vistec with threecomponent seismometers Lennartz LE3D/5s were used for the measurement. Frequency range of seismic channel was $0.2 \mathrm{~Hz}-50 \mathrm{~Hz}$; sampling frequency of digital signal was set to $100 \mathrm{~Hz}$. The seismometer of ST1 station was installed directly on the bedrock outcrop in the experimental gallery, where seismometers of seismic station OKC - Guralp CMG3ESP and SM3 are also installed. The seismometer of ST2 station was installed on the concrete seismic pillar in the seismic cellar (Fig. 3). Both seismometers were oriented according to geographical coordinates.

During the measurement, several seismic events were recorded at both temporary stations. These included mining induced seismic events from the Ostrava-Karviná Coalfield (epicentral distances 22 $30 \mathrm{~km}$ ), mining induced seismic events from the Polish part of Upper Silesian Coal Basin (epicentral distances $30-70 \mathrm{~km}$ ) and mining induced seismic 
Table 1 Geological profiles at the place of boreholes B1, B2 and B3 (according to the database of the Czech Geological Survey) and geological profile at the place of the seismic pillar (according to the internal report of the VŠB-Technical University of Ostrava, 1981).

* the bottom of seismic pillar is situated at the depth of $5 \mathrm{~m}$ below the surface

\begin{tabular}{|c|c|c|}
\hline depth $(m)$ & \multicolumn{2}{|c|}{ borehole B1 } \\
\hline $0-0.5$ & Quaternary sediments & clayey loam \\
\hline $0.5-4.5$ & Quaternary sediments & detritus \\
\hline $4.5-10.5$ & Carboniferous layers & highly weathered slates \\
\hline $10.5-17.3$ & Carboniferous layers & slightly weathered slates \\
\hline $17.3-19.2$ & Carboniferous layers & slates \\
\hline $19.2-25.1$ & Carboniferous layers & slightly weathered slates \\
\hline \multirow[t]{2}{*}{$23.1-26.3$} & Carboniferous layers & slates \\
\hline & \multicolumn{2}{|c|}{ borehole B2 } \\
\hline $0-4.0$ & Quaternary sediments & loam \\
\hline $4.0-7.0$ & Quaternary sediments & sand \\
\hline $7.0-7.3$ & Quaternary sediments & clayey loam \\
\hline $7.3-7.5$ & Quaternary sediments & gravel \\
\hline $7.5-7.8$ & Quaternary sediments & loam \\
\hline $7.8-9.0$ & Quaternary sediments & clayey loam \\
\hline $9.0-9.7$ & Quaternary sediments & gravel \\
\hline \multirow[t]{2}{*}{$9.7-10.0$} & Carboniferous layers & slightly weathered siltstone \\
\hline & \multicolumn{2}{|c|}{ borehole B3 } \\
\hline $0-2.7$ & Quaternary sediments & loam \\
\hline $2.7-4.7$ & Quaternary sediments & sandy loam \\
\hline $4.7-6.2$ & Quaternary sediments & sand \\
\hline $6.2-6.7$ & Quaternary sediments & loamy sand \\
\hline $6.7-8.0$ & Quaternary sediments & loam \\
\hline $8.0-8.7$ & Quaternary sediments & sandy loam \\
\hline \multirow[t]{2}{*}{$8.7-10.0$} & Carboniferous layers & slightly weathered slates \\
\hline & \multicolumn{2}{|c|}{ geological profile in the place of the seismic pillar * } \\
\hline $0-5.5$ & Quaternary sediments & clayey loam, sandy loam, loamy sand \\
\hline $5.5-10.4$ & Quaternary sediments & loamy sand, sand with gravel \\
\hline $10.4-11.0$ & Quaternary sediments & clayey loam, sandy loam, loamy sand \\
\hline $11.0-16.5$ & Quaternary sediments & loamy sand, sand with gravel \\
\hline bellow 16.5 & Carboniferous layers & siltstone, claystone \\
\hline
\end{tabular}
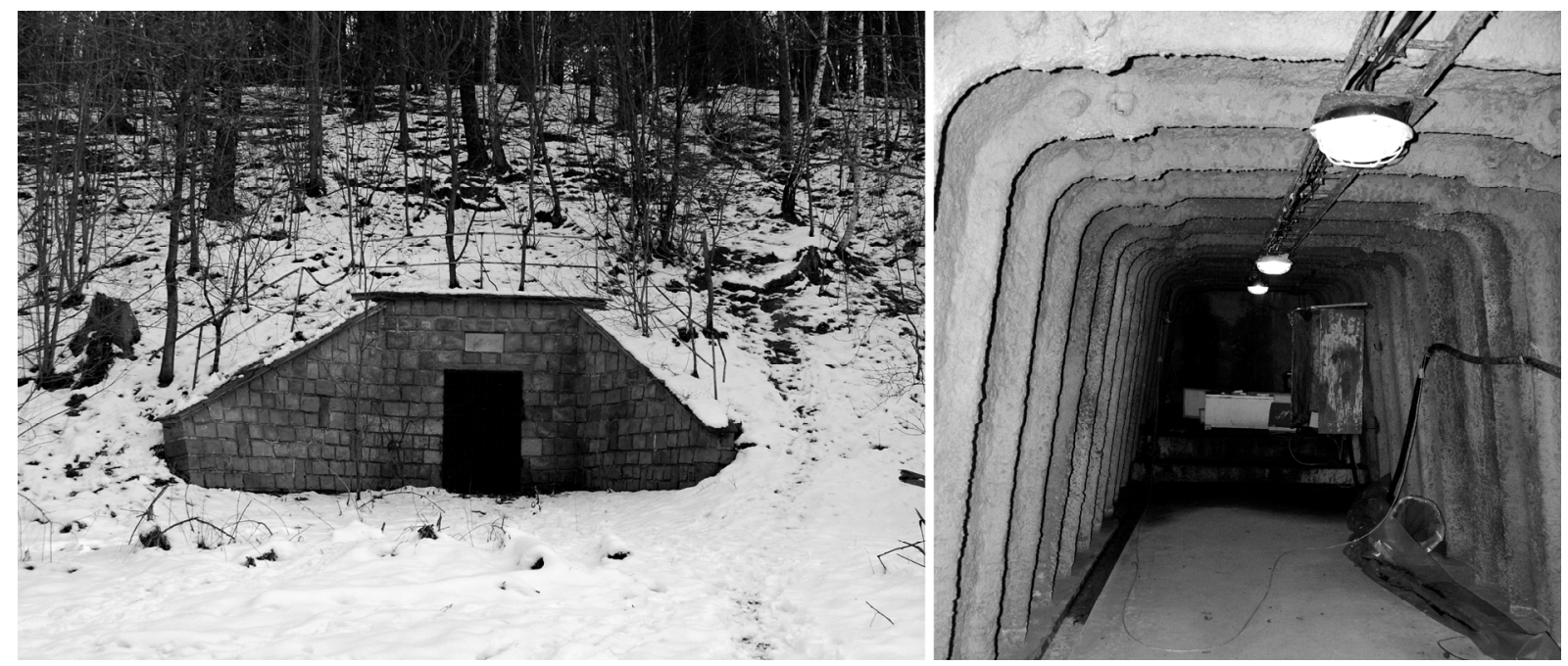

Fig. 2 Photo of the experimental gallery entrance (on the left) and view into the gallery (on the right, photo Lednická, January 2015). 

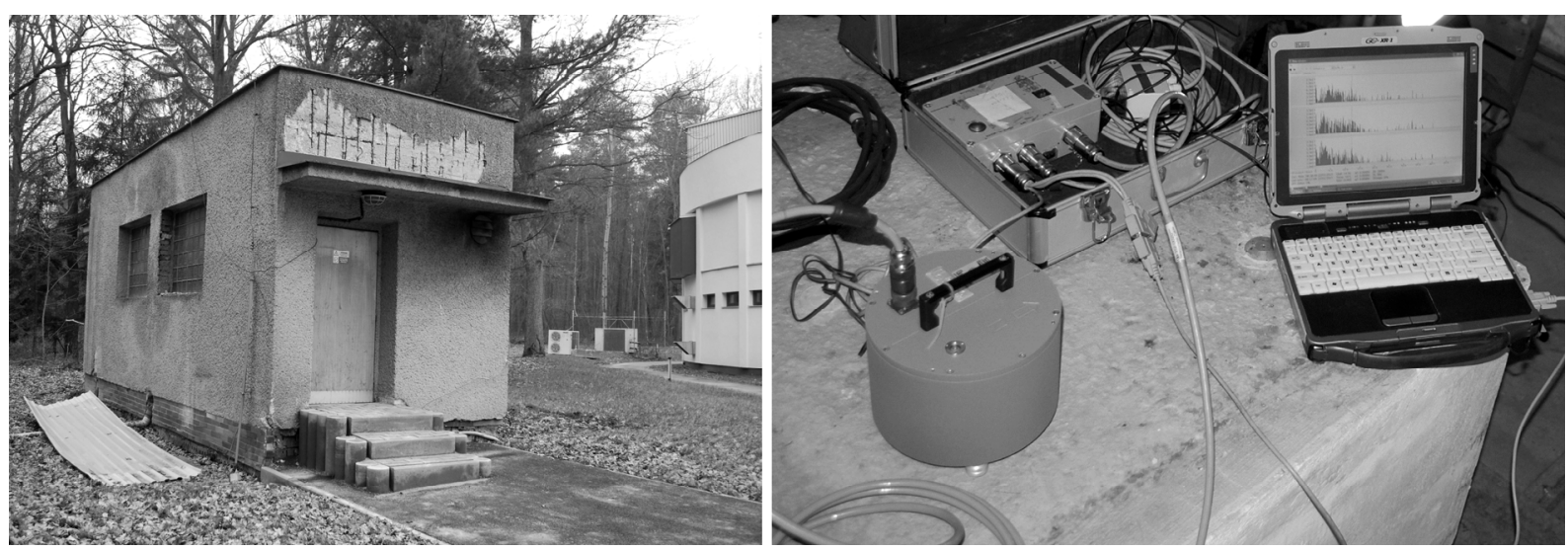

Fig. 3 Photo of the seismic cellar at the Johann Palisa Astronomical Observatory in Ostrava (on the left) and seismic station ST2 installed on the seismic pillar (on the right); seismometer Lennartz LE3D/5s with the recorder GAIA Vistec were used for the measurement (photo Lednická, January 2015).

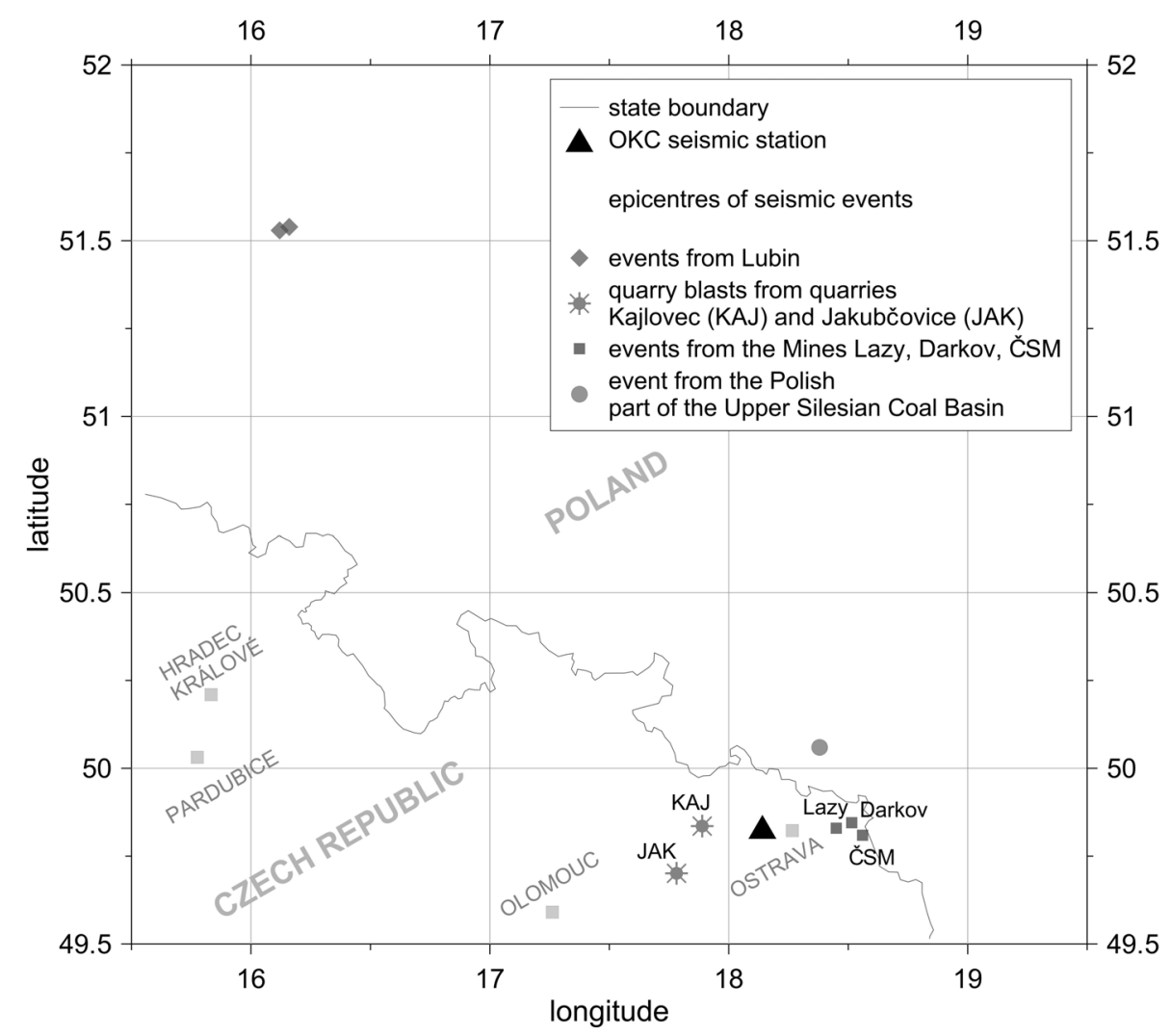

Fig. 4 Localization of the epicentres of analysed seismic events.

events from Lubin in Poland (epicenral distance approximately $230 \mathrm{~km}$ ). A few distant earthquakes were also recorded during the measurement, but these records were not analysed in this study.

At the end of the measurement, only station ST2 was in operation. During this time, quarry blasts from the quarries near Kajlovec (epicentral distance $18 \mathrm{~km}$ ) and Jakubčovice nad Odrou (epicentral distance $30 \mathrm{~km}$ ) were recorded. To analyse also these records, data from the $\mathrm{OKC}$ seismic station recorded by the seismometer Guralp CMG-3ESP were used for the frequency analysis instead of data of station ST1. Epicentres of analysed events are plotted into the map in Figure 4.

\section{DATA ANALYSIS}

Data analysis of measured events was performed in two phases. In the first phase, frequency analysis was performed for the five events selected, with different epicentral distances and from different 
Table 2 Parameters of analysed seismic events according the "Bulletins of seismic events recorded by the Czech Regional Seismological Network" (www.czechgeo.cz) and the "Database of mining induced events" of Green Gas, DPB a.s. (www.dpb.cz/geofyzika). Used symbols - mb (body wave magnitude), ML (local magnitude), EMSC (European-Mediterranean Seismological Centre, France), USCB (Upper Silesian Coal Basin).

\begin{tabular}{rcccccc}
\hline Date & $\begin{array}{c}\text { Time } \\
\text { (UTC) }\end{array}$ & Lat & Lon & $\begin{array}{c}\text { Magnitude/ } \\
\text { Energy (J) }\end{array}$ & Agency \\
\hline 28.1. & 011043.0 & 51.54 & 16.16 & mb 4.3 & Poland - Lubin & EMSC \\
29.1. & 083607.3 & 50.11 & 18.40 & ML 3.2 & Poland - USCB & EMSC \\
1.2. & 164208.0 & 49.85 & 18.52 & $9.53 \mathrm{E}+04$ & Darkov Mine - destress blasting & GreenGas \\
2.2. & 064835.0 & 49.83 & 18.45 & $1.86 \mathrm{E}+04$ & Lazy Mine & GreenGas \\
4.2. & 190152.0 & 49.85 & 18.51 & $8.33 \mathrm{E}+04$ & Darkov Mine & GreenGas \\
5.2. & 044357.2 & 51.53 & 16.12 & ML 3.9 & Poland - Lubin & EMSC \\
5.2. & 045218.0 & 49.83 & 18.55 & $3.43 \mathrm{E}+04$ & ČSM Mine & GreenGas \\
21.3. & 224503.0 & 49.84 & 18.52 & $2.39 \mathrm{E}+05$ & Darkov Mine - mining shock & GreenGas \\
\hline
\end{tabular}

azimuth - mining induced events from Poland (one event from Lubin and one event from the Upper Silesian Coal Basin), mining induced event from the locality of the Darkov Mine (Ostrava-Karviná Coalfield) with the energy 2.6E+05 J (according to the Database of Green Gas, DPB a.s.) and two quarry blasts from the quarries near Kajlovec and Jakubčovice nad Odrou (Fig. 4). Records of events with all wave groups were used for the frequency analysis in this study. Software Sigview (Sigview, 2015) was used for the FFT amplitude spectra computation (Hamming window) and resulting spectra of individual components for both seismic stations were compared.

In the second phase of data analysis, three spectral ratio methods were used for the determination of site effect at station ST2, located on the sediments, i.e. the SSR, HVSR and HVNR method. For the application of the SSR and HVSR methods, we have only used the events recorded by identical seismometers, i.e. the records of quarry blasts were not analysed by the spectral ratio methods. The analysed data set contains 7 records of mining induced events from the Czech Republic and Poland and one destress blasting from the locality of the Darkov Mine, for the parameters of analysed events see Table 2.

Amplitude spectra for both horizontal and vertical components were calculated using the FFT algorithm with Hamming window and obtained curves were smoothed with a spline function. Two horizontal spectra (NS and EW component) were averaged to form one horizontal spectrum using quadratic mean. After this, spectral ratio SSR was calculated using averaged horizontal spectra computed separately for ST1 and ST2 station. Spectral ratio HVSR was calculated using averaged horizontal spectrum and vertical spectrum only for ST2 station.

Records of seismic noise were analysed by the HVNR method separately for both stations ST1 and
ST2. This method uses the noise as a seismic input and computes the horizontal-to-vertical spectral ratio between the horizontal and vertical components. The data were analysed using Geopsy software (Wathelet et al., 2011). Continual record of seismic noise measured during the night was used for the computation. The duration of selected record was approximately 2 hours and more than 100 windows of the length of $60 \mathrm{~s}$ were analysed in each record. Before computing the spectral ratio, Fourier spectra amplitudes of three components were smoothed with the Konno-Ohmachi smoothing function with a smoothing constant equal to 40 and the spectra of two horizontal components were averaged using a quadractic mean. The resulting spectral ratio curves show the averaged curve and its standard deviation computed for all selected windows.

\section{RESULTS AND DISCUSSION}

Results of the first phase of the data analysis, i.e. records of the five events selected together with the amplitude spectra calculated for individual components are presented in Figures 5 - 9. Amplitude spectra are displayed for the frequency range $0.2-$ $10 \mathrm{~Hz}$. This range results from the parameters of used seismometers (the eigenfrequency of seismometer Lennartz LE3D $/ 5 \mathrm{~s}$ is $0.2 \mathrm{~Hz}$ ) and from the parameters of recording (sampling frequency of the data recorded by the seismometer Guralp CMG-3ESP is $20 \mathrm{~Hz}$ ). This frequency range is sufficient for the data analysis because it covers all prevailing frequencies of recorded wave groups of the analysed events. If we compare vibration effect at ST1 (black line) and ST2 (red line) stations, the measured values of vibration velocity are significantly higher for all three components at the place with sedimentary layers, with the significant maxima at the horizontal components in the frequency range approximately $1.5-5 \mathrm{~Hz}$. For the frequencies below $1.0 \mathrm{~Hz}$, the frequency content of recorded signal at both stations is practically the 
same. This may be seen in detail especially in the amplitude spectra of the events with the wave groups of prevailing frequencies below $1.0 \mathrm{~Hz}$; e.g. the mining induced event from the Polish part of Upper Silesian Coal Basin (Fig. 6) and the mining induced event from Lubin in Poland (Fig. 7). Spectral contents are the same for the frequencies below $1.0 \mathrm{~Hz}$ also for the records of quarry blasts (Figs. 8, 9); even if the records of two different seismometers were used for the computation (Lennartz LE3D/5s for the soil site and Guralp CMG-3ESP for the bedrock site).

Resulting spectral ratio curves determined by the SSR, HVSR and HVNR method in the second phase of the data analysis are presented in Figures 10 and 11. No curves calculated for station ST2 show any amplification of seismic effect below the frequency of $1.0 \mathrm{~Hz}$ that corresponds with the amplitude spectra analysis performed in the first phase of the data analysis. The HVSR and HVNR curves have similar shape with the amplification in the frequency range $1.0-4.0 \mathrm{~Hz}$ and with the peak at the frequency $2.7 \mathrm{~Hz}$ (HVNR) and $3.2 \mathrm{~Hz}$ (HVSR). The SSR curve exhibits main peak at the frequency $3.1 \mathrm{~Hz}$. The amplification derived from the SSR curve is equal to 6.5 and it is almost twice the amplification 3.5 derived from the HVSR and HVNR curves. These results corresponds with findings presented e.g. by Haghshenas et al. (2008) and Lachet et al. (1996). Amplitudes obtained from the HVSR and HVNR curves underestimate amplitudes obtained from the SSR curves, that usually give the real amplification of investigated site.

The most intensive seismic events from individual epicentral areas recorded during the experimental measurement were used for the SSR and HVSR computations. Nevertheless the signal-to-noise ratio was greater than 3 for all events at both sites only in the frequency range approximately from 0.7 to $7 \mathrm{~Hz}$. It means that the SSR amplification above the frequency $7 \mathrm{~Hz}$ can be significantly influenced by the noise of the sites and it can be not considered in the real site effect evaluation. Especially the station ST2 located in the place of astronomical observatory near an inhabited area is more affected by the cultural noise, for which the frequency range above $1.0 \mathrm{~Hz}$ is
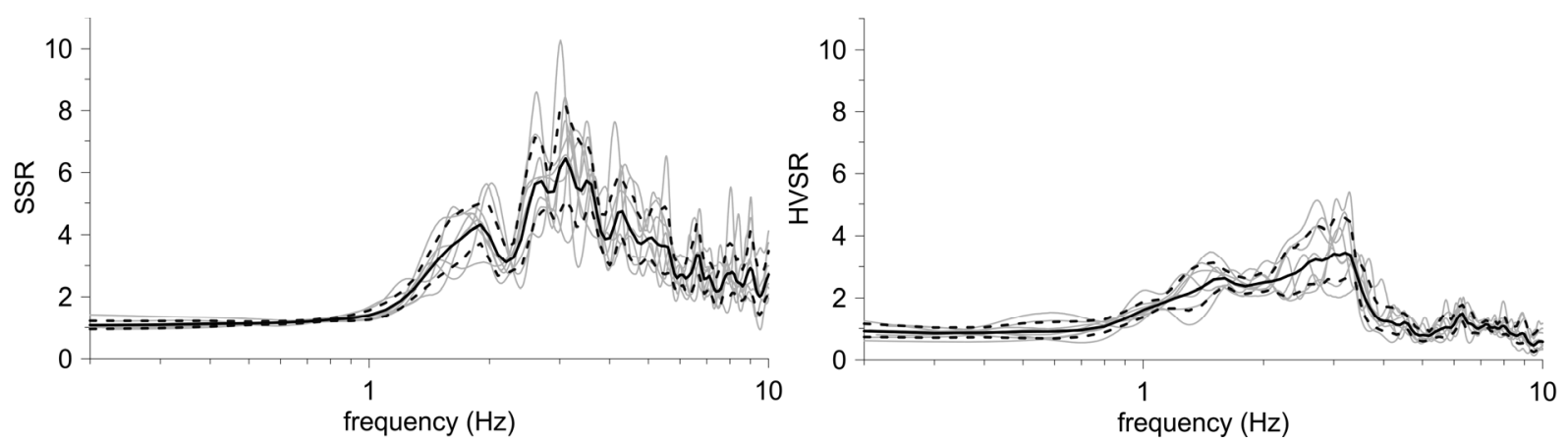

Fig. 10 Spectral ratio curves calculated for station ST2 using SSR method (on the left) and HVSR method (on the right); the graphs show individual spectral ratio curves, the averaged curve and its standard deviation computed for all selected events in the analysed data set (see Table 2)
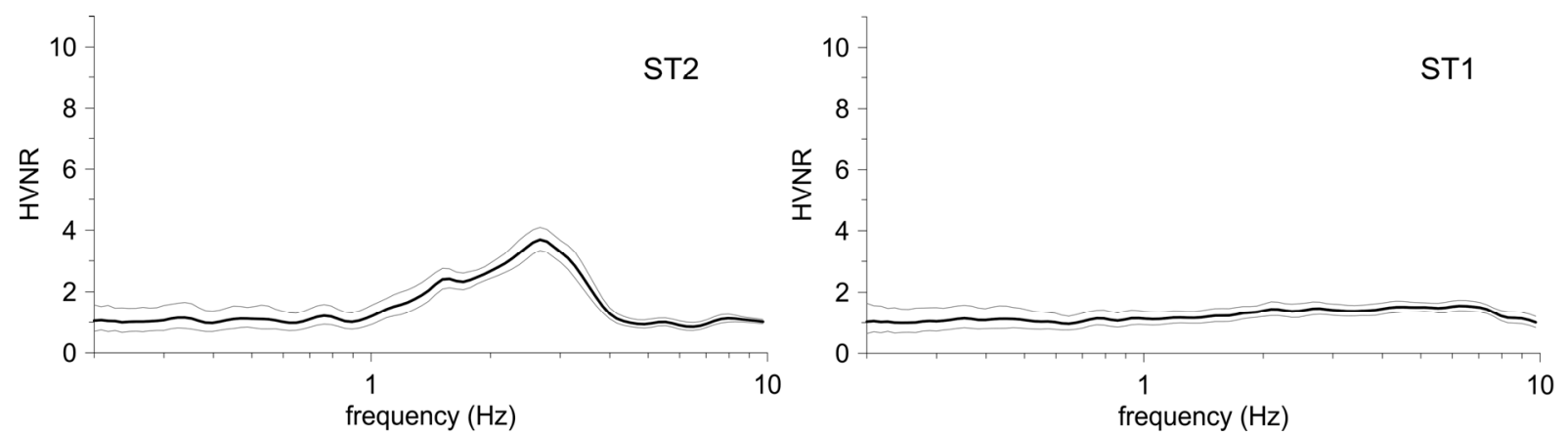

Fig. 11 Spectral ratio curves calculated for station ST1 (on the right) and ST2 (on the left), using HVNR method; spectral ratio curves show the averaged curve and its standard deviation computed for all selected windows. 

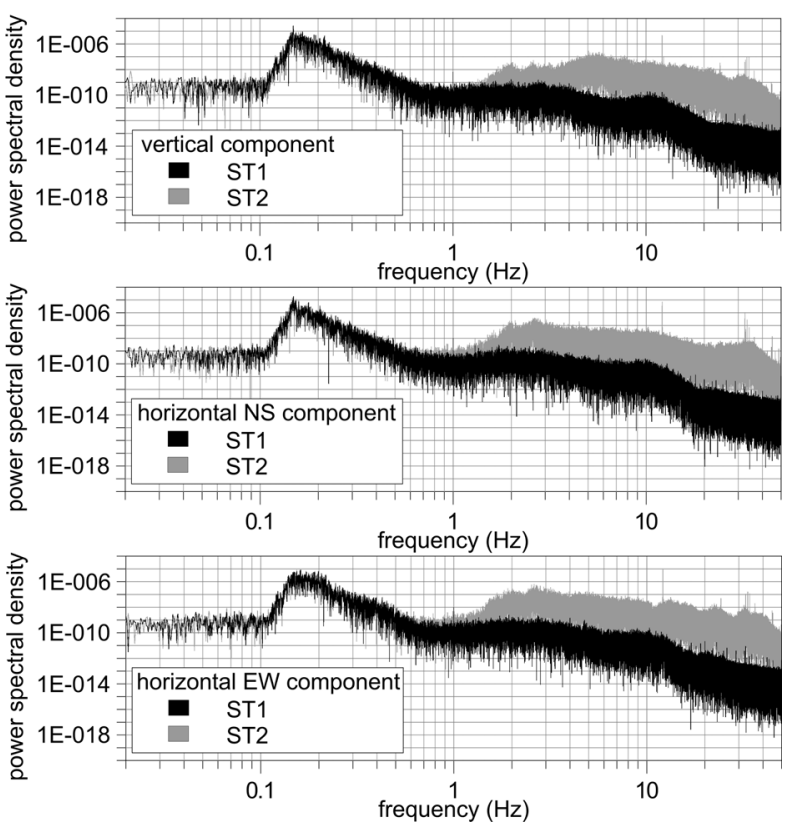

Fig. 12 Power spectral density calculated for individual components of the station ST1 (black curve) and ST2 (grey curve).

typical (Bonnefoy-Claudet et al., 2006). To see how strong the station ST2 is affected by the cultural noise, ambient noise power spectral density was calculated for both sites using continual record of ambient noise measured during the daytime. The duration of analysed records was one hour and the comparison of power spectral density for individual components is presented in Figure 12.

To verify determined resonance frequency of sedimentary layers, the simple formula was used

$f=\frac{v_{s}}{4 h}$

where $\mathrm{h}$ is the thickness of the sedimentary layer and $v_{s}$ is the average shear wave velocity in this layer. Determined average shear wave velocity is approximately $200 \mathrm{~m} . \mathrm{s}^{-1}$ considering resonant frequency equal to $3.1 \mathrm{~Hz}$ (based on SSR method) and thickness of sediments $16.5 \mathrm{~m}$ at the place of station ST2. According to ground types introduced in the European standard (EN 1998-1, 2004), this shear wave velocity corresponds well with the ground type $\mathrm{C}$, it means deposits of dense or medium dense sand, gravel or stiff clay. For this ground type, the average value of propagation velocity of shear waves in the upper $30 \mathrm{~m}$ of the soil profile $\mathrm{v}_{\mathrm{s}, 30}$ is indicated in the range $180-360 \mathrm{~m} \cdot \mathrm{s}^{-1}$.

The HVNR curve was calculated also for the bedrock site ST1 to see if there exists a slight site effect due to local geological pattern formed by the weathered slates. Spectral ratio curve presented in
Figure 11 has an almost flat shape with no amplification. This means that station ST1 fulfilled the requirements for a reference station when using the SSR method.

\section{CONCLUSION}

The main aim of this paper was an evaluation of site effect at the locality of seismic station OstravaKrásné Pole (OKC). The presented analysis of events recorded simultaneously at two sites with different geological conditions proved the existence of differences in the amplitude and the frequency domain. The analysed data set contained mainly records of mining induced seismic events from the Czech Republic and Poland and also records of quarry blasts from nearby quarries. Moreover, seismic noise recorded at both sites was analysed to study site effect. At the soil site, which consists of $16.5 \mathrm{~m}$ thick Quaternary sediments overlying Carboniferous layers, amplification of seismic effect was proved by spectral analysis of recorded events and also using different spectral ratio methods - SSR, HVSR and HVNR. The resulting spectral ratio curves obtained by the HVSR and HVNR methods exhibit similar shapes with the amplification effect in the frequency range $1.0-$ 4.0 Hz. Nevertheless the amplification of the HVSR and HVNR curves underestimates the amplification derived from the SSR curve. Considering the results of the SSR method, that is the most reliable for site effect evaluation, the main peak was detected at the frequency approximately $3.1 \mathrm{~Hz}$ with the amplification equal to 6.5. No amplification effect was documented at the bedrock site using HVNR method, even though the shallow experimental gallery representing the bedrock site is driven in the layer of weathered slates.

The findings presented in this paper complete the results obtained from a former analysis of seismic noise which was performed at the locality (e.g. Holub et al., 2007). Further research will be focused on detailed analysis of individual seismic events of different origin, with different epicentral distances and different azimuth to see e.g. azimuthal variations of site effect at the locality.

\section{ACKNOWLEDGEMENT:}

This research has been performed with the financial support of the Czech Science Foundation, No. 13-07027P "Investigation of the seismic characteristics of foundation soils using frequency analysis of vibration effects" and with the long-term conceptual development support of research organisations RVO: 68145535. The data acquisition was supported by the project of large research infrastructure CzechGeo/EPOS, Grant No. LM2010008. Presented borehole data are from the database of the Czech Geological Survey. The autors wish to thank Radim Chalupa for the help with the measurement. 


\section{REFERENCES}

Ansal, A. (ed.): 2004, Recent Advances in Earthquake Geotechnical Engineering and Microzonation. Series: Geotechnical, Geological and Earthquake Engineering, 1, Kluwer Academic Publishers, Dordrecht, $354 \mathrm{pp}$.

Ansal, A., Kurtuluş, A. and Tönük, G.: 2010, Seismic microzonation and earthquake damage scenarios for urban areas. Soil Dynamics and Earthquake Engineering, 30, No. 11, 1319-1328. DOI: $10.1016 /$ j.soildyn.2010.06.004

Bard, P.-Y. (ed.): 2008, Bulletin of Earthquake Engineering, Special Issue: The H/V Technique: Results of the SESAME Project, 6, No. 1, Springer, Dordrecht, 147 pp.

Bonnefoy-Claudet, S., Cotton, F. and Bard, P.-Y.: 2006, The nature of noise wavefield and its applications for site effects studies - A literature review. Earth-Science Reviews, 79, No. 3-4, 205-227. DOI: $10.1016 /$ j.earscirev.2006.07.004

Borcherdt, R.D.: 1970, Effects of local geology on ground motion near San Francisco Bay. Bull. Seism. Soc. Am., 60, No. 1, 29-61.

Bulletins of seismic events recorded by the Czech Regional Seismological Network: www.czechgeo.cz, cit. June 2015.

Database of Green Gas, DPB a.s.: www.dpb.cz/geofyzika, cit. June 2015.

Documentation of subsurface geology at the place of seismic pillar: 1981, internal report, VSB - Technical University Ostrava, 3 pp., (in Czech).

EN 1998-1: 2004, Eurocode 8: Design of structures for earthquake resistance - Part 1: General rules, seismic actions and rules for buildings. European committee for standardization.

Haghshenas, E., Bard, P.-Y. and Theodulidis, N.: 2008, Empirical evaluation of microtremor $\mathrm{H} / \mathrm{V}$ spectral ratio. Bull. Earthquake Eng., 6, No. 1, 75-108. DOI: $10.1007 / \mathrm{s} 10518-007-9058-\mathrm{x}$

Holub, K., Knejzlík, J. and Rušajová, J.: 2007, Site response investigation at the seismological station OstravaKrásné Pole (OKC). Acta Montanistica Slovaca, 12, No. 2, 243-248.

Holub, K., Kaláb, Z., Knejzlík, J. and Rušajová, J.: 2009, Contribution of the Institute of Geonics of the ASCR Ostrava to seismolological monitoring in Silesia and Northern Moravia. Acta Geodyn. Geomater., 6, No. 3 (155), 391-398.
Lachet, C., Hatzfeld, D., Bard, P.-Y., Theodulidis, N., Papaioannou, Ch. and Savvaidis, A.: 1996, Site effects and microzonation in the city of Thessaloniki (Greece). Comparison of different approaches. Bull. Seism. Soc. Am., 86, No. 6, 1692-1703.

Lermo, J. and Chávez-García, F. J.: 1993, Site effect evaluation using spectral ratios with only one station. Bull. Seism. Soc. Am., 83, No. 5, 1574-1594.

Nakamura, Y.: 1989, A method for dynamic characteristics estimation of subsurface using microtremor on the ground surface. Quart Rep Railway Tech Res Inst, 30, No. 1, 25-33.

Panzera, F., Lombardo, G., D'Amico, S. and Galea, P.: 2013, Speedy techniques to evaluate seismic site effects in particular geomorphologic conditions: faults, cavities, landslides and topographic irregularities. In: D'Amico, S. (Ed.): Engineering Seismology, Geotechnical and Structural Earthquake Engineering, InTech, 101-145. DOI: 10.5772/55439 Available from:

http://www.intechopen.com/books/howtoreference/en gineering-seismology-geotechnical-andstructuralearthquake-engineering/speedy-techniquestoevaluate-seismic-site-effects-inparticulargeomorphologic-conditions-faults-ca

Pitilakis, K.: 2004, Site effect, In: Ansal, A. (Ed.): Recent advance in earthquake geotechnical engineering and microzonation, Kluwer Academic Publisher, Dordrecht, 139-197.

Sigview: 2015, SIGVIEW32 Version 2.6.0, Signal analysis software, copyright (C) 1998-2013 SIGVIEW.com

Steidl, J. H., Tumarkin, A. G. and Archuleta, R. J.: 1996, What is a reference site? Bull. Seism. Soc. Am., 86, No. 6, 1733-1748.

Wathelet, M. et al.: 2011, Geophysical signal database for noise array processing (GEOPSY), free download available at the web-site: http://www.geopsy.org/download.php 

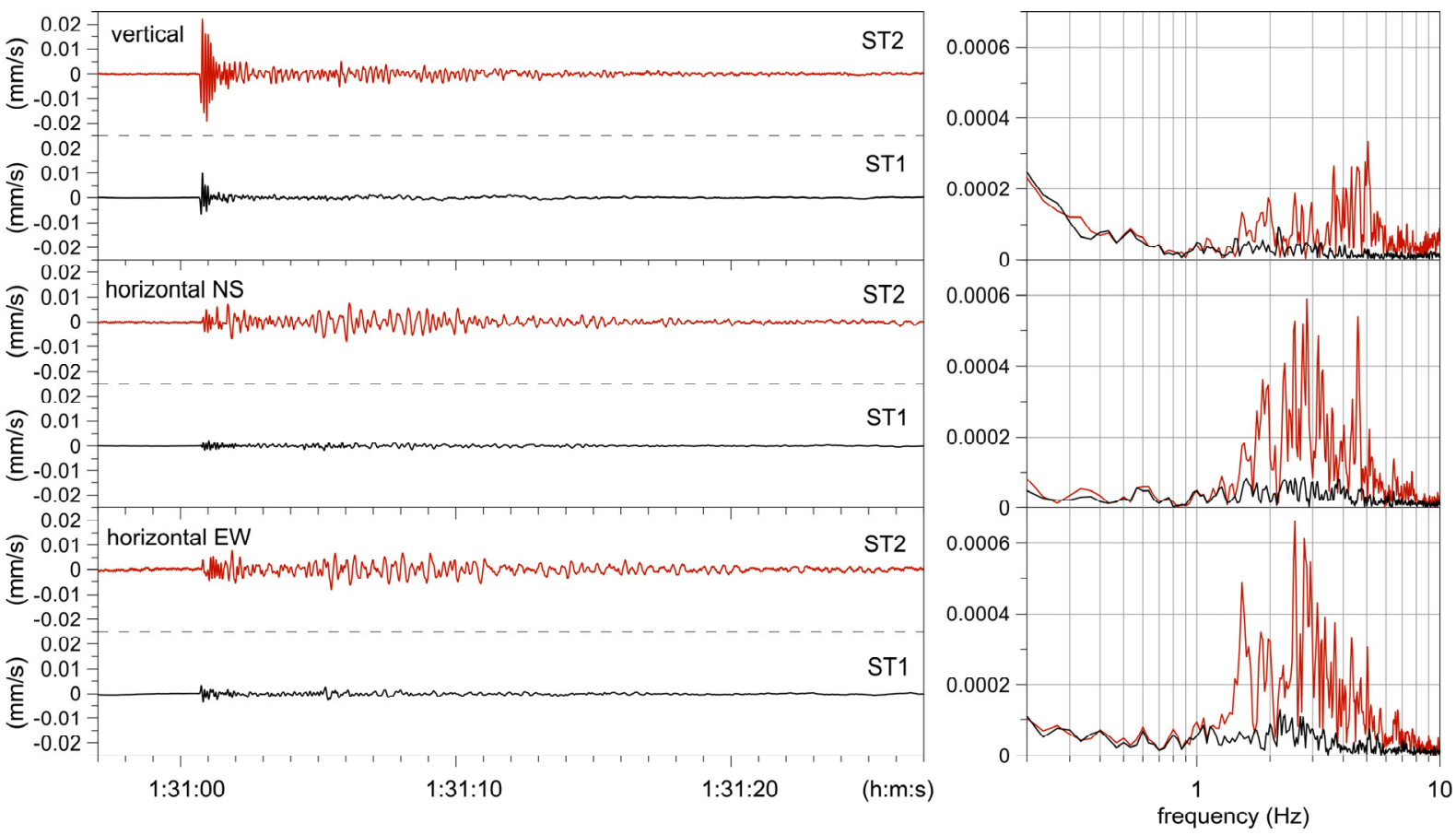

Fig. 5 Mining induced seismic event occurring on January 26, 2015 in the Ostrava-Karviná Coalfield recorded at seismic stations ST1 (experimental gallery, the bedrock site) and ST2 (seismic cellar, the soil site); locality of the Darkov Mine, released seismic energy 2.6E $+05 \mathrm{~J}$ (according to the database of Green Gas, DPB a.s.; www.dpb.cz/geofyzika), epicentral distance $d=26 \mathrm{~km}$. Calculated amplitude spectra of individual components are also presented.
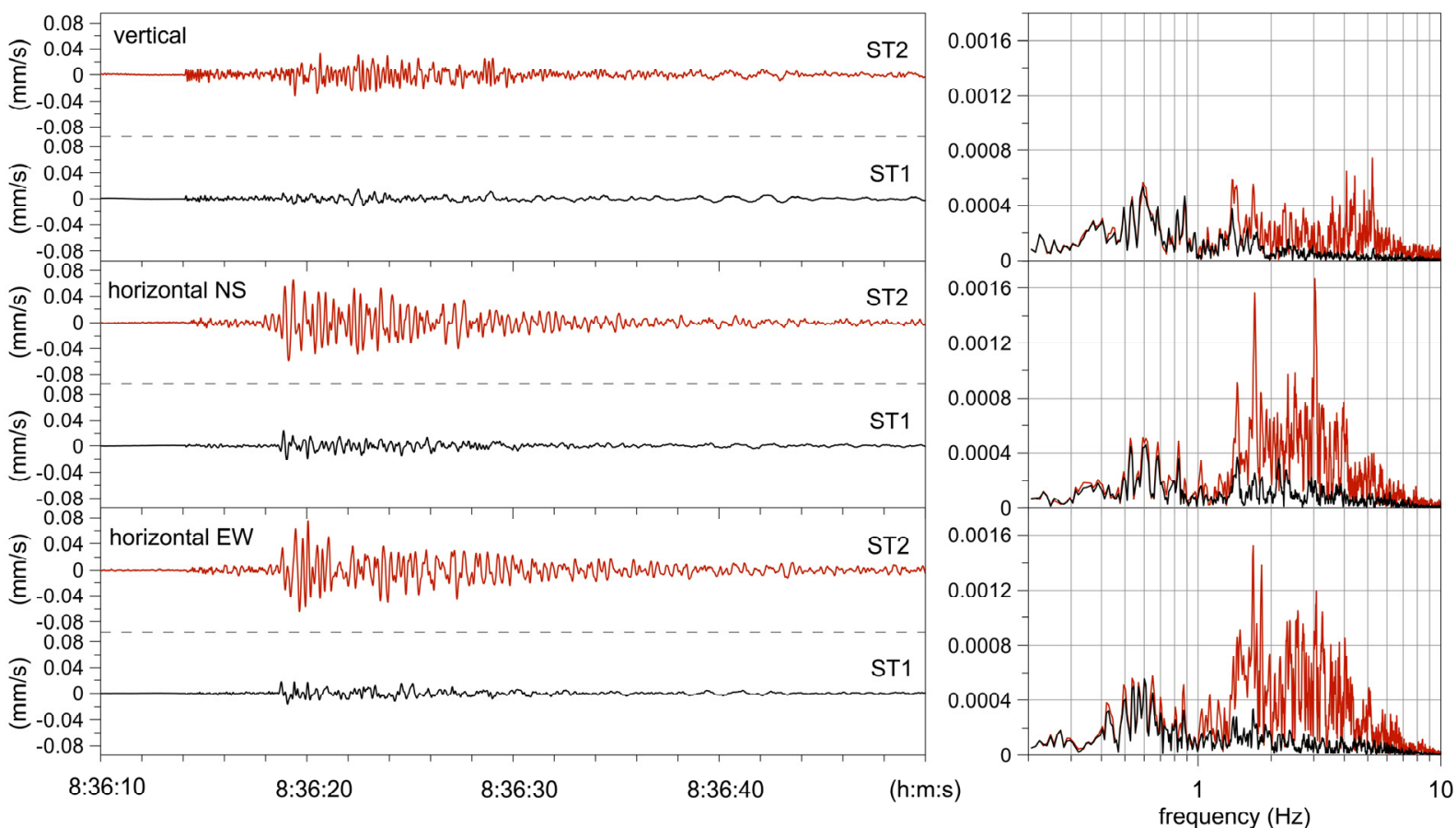

Fig. 6 Mining induced seismic event occurring on January 29, 2015 in the Polish part of Upper Silesian Coal Basin recorded at seismic stations ST1 (experimental gallery, the bedrock site) and ST2 (seismic cellar, the soil site); epicentral distance $\mathrm{d}=30 \mathrm{~km}$. Calculated amplitude spectra of individual components are also presented. 

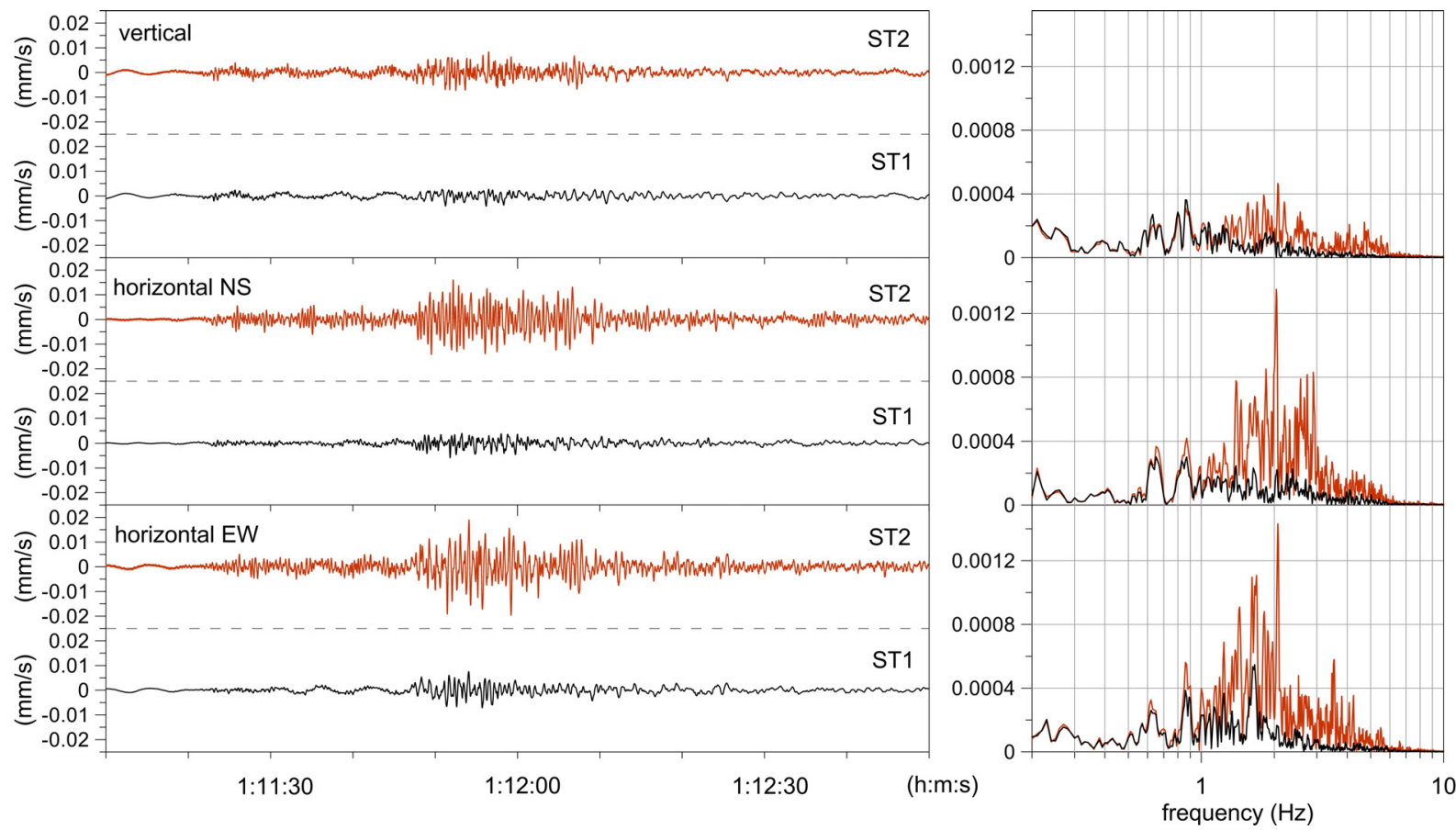

Fig. 7 Mining induced seismic event occurring on January 28, 2015 in the Lubin area in Poland recorded at seismic stations ST1 (experimental gallery, the bedrock site) and ST2 (seismic cellar, the soil site); epicentral distance $\mathrm{d}=230 \mathrm{~km}$. Calculated amplitude spectra of individual components are also presented.
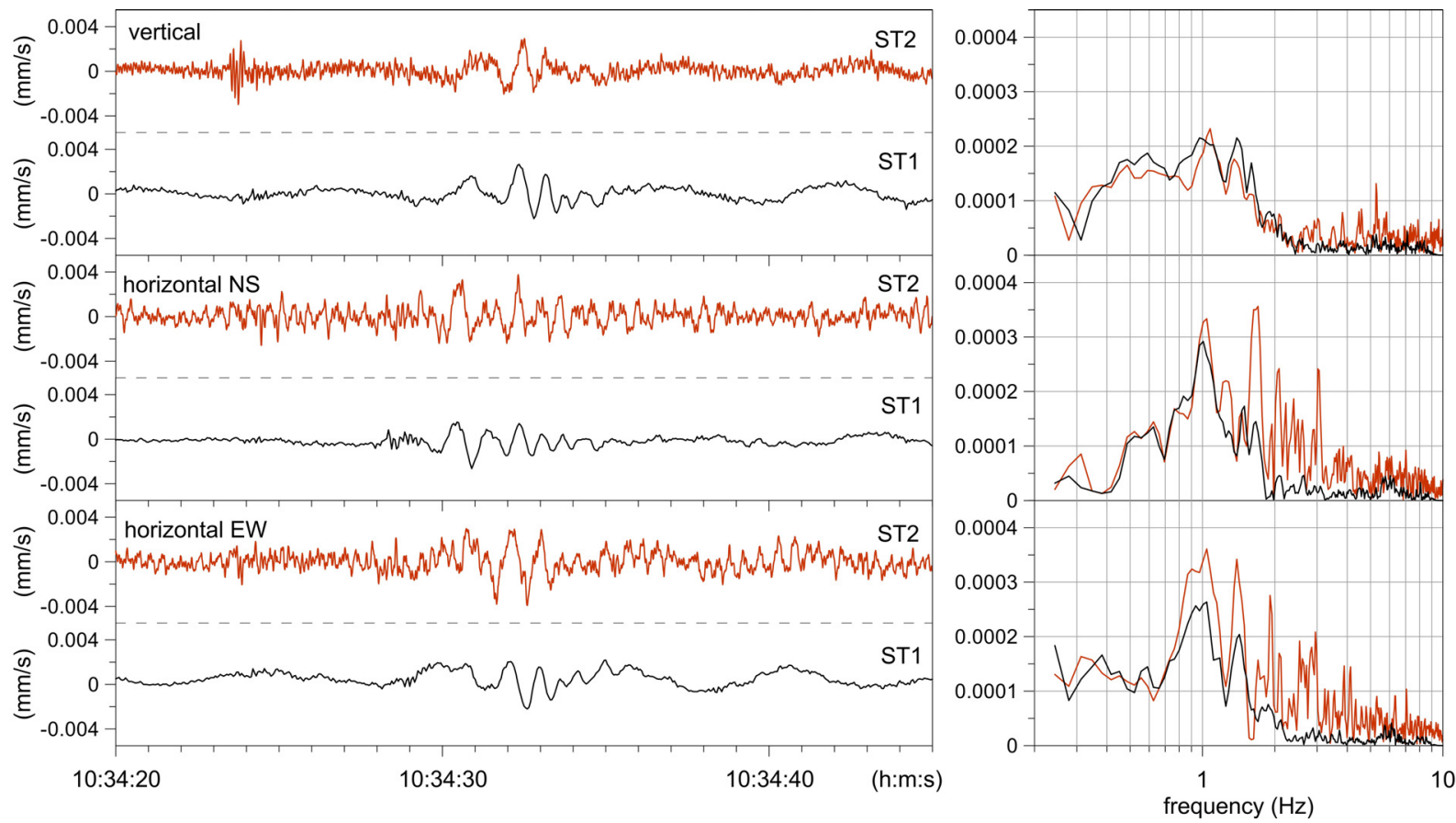

Fig. 8 Quarry blast realized on March 24, 2015 in the quarry near Jakubčovice nad Odrou recorded at seismic stations ST1 (experimental gallery, the bedrock site) and ST2 (seismic cellar, the soil site); epicentral distance $\mathrm{d}=30 \mathrm{~km}$. Calculated amplitude spectra of individual components are also presented. 

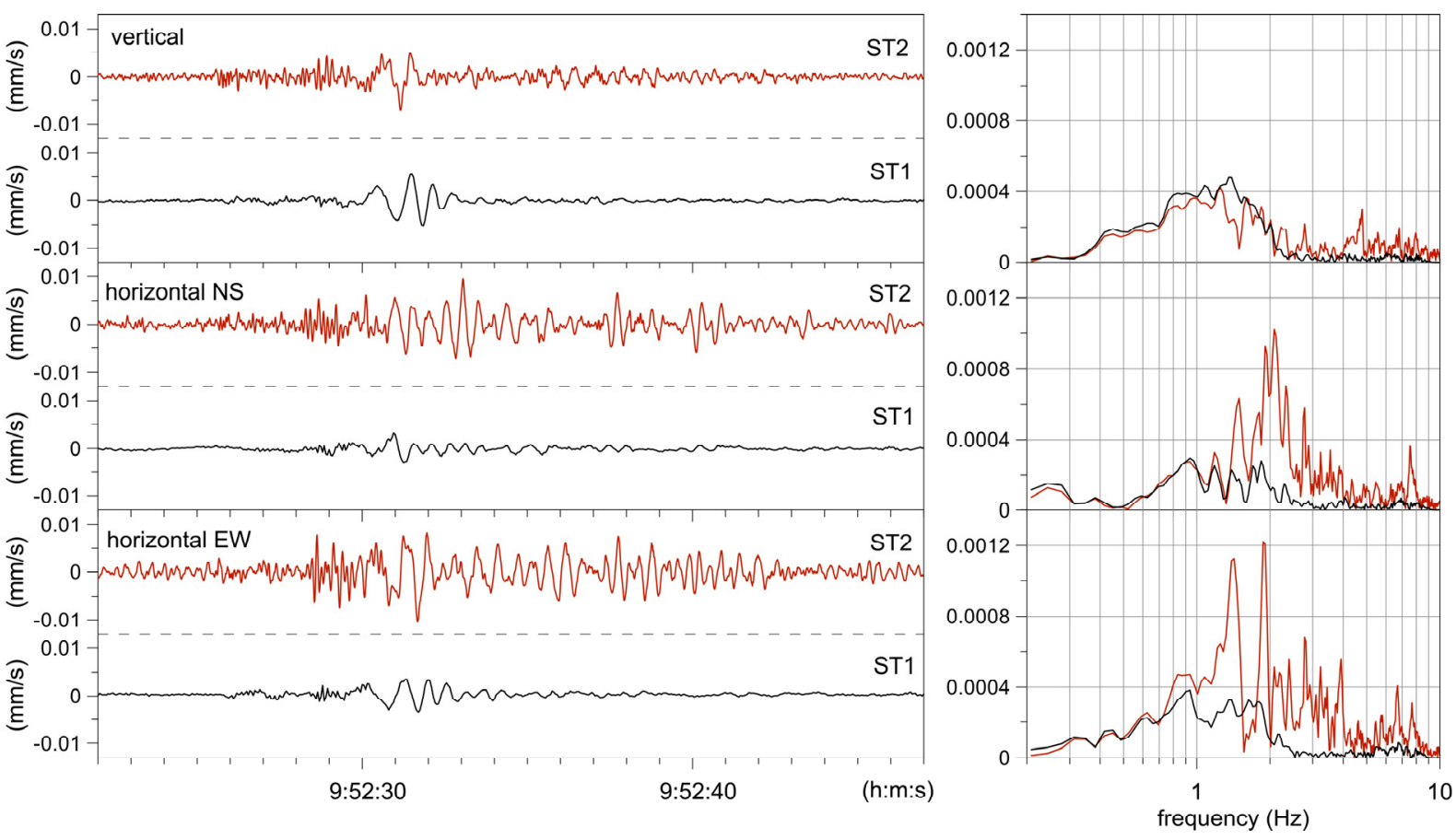

Fig. 9 Quarry blast realized on March 26, 2015 in the quarry near Kajlovec recorded at seismic stations ST1 (experimental gallery, the bedrock site) and ST2 (seismic cellar, the soil site); epicentral distance $\mathrm{d}=18 \mathrm{~km}$. Calculated amplitude spectra of individual components are also presented. 